Abstracta Iranica

Revue bibliographique pour le domaine irano-aryen

Volume 34-35-36 | 2017

Comptes rendus des publications de 2011-2013

\title{
Gilles Authier. Grammaire juhuri, ou judéo-tat, langue iranienne des Juifs du Caucase de l'est
}

\section{Thomas Jügel}

\section{Q OpenEdition \\ 1 Journals}

\section{Electronic version}

URL: http://journals.openedition.org/abstractairanica/41150

DOI: 10.4000/abstractairanica.41150

ISSN: 1961-960X

Publisher:

CNRS (UMR 7528 Mondes iraniens et indiens), Éditions de l'IFRI

\section{Electronic reference}

Thomas Jügel, « Gilles Authier. Grammaire juhuri, ou judéo-tat, langue iranienne des Juifs du Caucase de l'est », Abstracta Iranica [Online], Volume 34-35-36 | 2017, document 5, Online since 15 July 2016, connection on 27 September 2020. URL : http://journals.openedition.org/abstractairanica/41150 ; DOI : https://doi.org/10.4000/abstractairanica.41150

This text was automatically generated on 27 September 2020.

Tous droits réservés 


\title{
Gilles Authier. Grammaire juhuri, ou judéo-tat, langue iranienne des Juifs du Caucase de l'est
}

\author{
Thomas Jügel
}

\section{REFERENCES}

Gilles Authier. Grammaire juhuri, ou judéo-tat, langue iranienne des Juifs du Caucase de l'est. Wiesbaden, Reichert, 2012, 336 p. (Beiträge zur Iranistik 36 - Bibliothèque iranienne 76)

1 Juhuri or Judeo-Tat belongs to the Southwestern language group 'Tat' (not to be confused with Northwestern Tat in Iran) which is mostly spoken in scattered pockets in the Republic of Azerbaijan. Its closeness to Persian is obvious as are substantial differences. Moreover, the various dialects differ considerably (cf. chapters 1.5.5 and 1.6). As such, Juhuri represents an important reference for relative chronology of language change in SW Iranian as well as for language contact in general. Its characteristic of being a Jewish variety makes it a valuable object for sociolinguistics.

2 The author based his study on Juhuri literature published in the 20th century and he gives a comprehensive overview of all aspects of grammar: phonology, morphology, and syntax. All functions are displayed with numerous examples. Seven texts (two of which with translations) and a glossary round out the survey. The detailed list of contents facilitates the use, all the more because the author deviates a little from what one may call the traditional standard. Chapter 2 on nouns concentrates on the lexical aspect of nouns and consequently contains derivation. The following chapter 3 on form and function of nominal groups describes how a noun appears in syntax: with determiners, adpositions grammaticalised as case markers, and coordination. Next comes chapter 4 on adjectives, which combines lexical and syntactical information. The combination of nouns and adjectives is explained here and in chapter 6. Inbetween, in chapter 5 , the author exemplifies marking of number (synthetically by means of a 
plural suffix and analytically by means of quantifiers). Chapter 7 on adverbs and adpositions is followed by chapter 8 on pronouns. The link between nominal and verbal constructions is chapter 9 on the copula and on non-verbal clauses. As with the nouns, information on verbs is devided into a purely lexical chapter (including prefixes, complex verbs, etc.) and a morphological one (grammatical forms). With respect to the terminological dilemma whether to follow traditional terminology or whether to create a new term that reflects the functional range of a form, the author opted for the latter. The "thème 1 virtuel" corresponds to what is commonly referred to as 'present stem', and the "thème 2 factuel" to the 'past stem'. The morphological analysis is synchronic, e.g. (p. 169) "to ask" pürs-i-re instead of pürs-ir-e, cf. Persian pors-ìd-an. Chapter 12 discusses valency and topicalisation, chapter 13 focus strategies and interrogations, and the following chapters various forms of subordination (complement clauses, relative clauses, conditionals, etc.). The author concludes the grammar with chapter 17 on coordination.

3 This book represents a detailed linguistic description of a hitherto poorly known language. Its importance cannot be underestimated regarding the rapid language shift we observe with many minority languages of today and the relevance of Tat for many fields of Iranian and Caucasian studies.

\section{AUTHORS}

THOMAS JÜGEL

Mondes iranien et indien, Paris 